UDC 32.019 .52

Submitted: 20.10 .2017

LBC 66.3(2Poc)

Accepted: 10.04 .2018

\title{
RELIGIOUS AND POLITICAL ATTITUDES IN THE MASS CONSCIOUSNESS OF DAGESTAN YOUTH ${ }^{1}$
}

\author{
Ruslan M. Mamaraev \\ Institute for History, Archaeology and Ethnography of the Dagestan Scientific Centre, \\ Russian Academy of Sciences, Makhachkala, Russian Federation
}

\begin{abstract}
The study of religious and political attitudes of young people at the all-Russian and regional levels is always of great interest for the research community. The paper is based on the results of a mass political and sociological survey of 1220 young people (aged from 18 to 25 years old) of the Republic of Dagestan in 2017. The sociological survey was conducted throughout Dagestan, among young men and women living in cities and rural areas. The study touches upon the assessment of religious revival, the characteristics of the religious situation in Dagestan, the aggravation of the religious situation in the republic, the youth's preferences for social and State organization, the orientation of contacts with Islamic states, the attitudes of youth to ISIS and the likelihood of their participation in the ranks of ISIS and other religion-based terrorist organizations, the attitude of youth towards the military actions of Russia against ISIS in Syria, the sources of religious information, reflecting the religious component on interethnic relations.

The study shows that the level of religiosity among Dagestan youth is at a high level, which is especially evident in some issues, and this causes some concern. However, this phenomenon is not critical. Young people remain oriented towards secularism in the State system. For young people, the economic and political factor is more important than the religious one, which has more spiritual and moral significance. The youth is aware of and supports the foreign policy course of the country's leadership and approves the military-political policy in Syria.

Key words: Islam, sharia, society, terrorism, the Middle East, the Russian Aerospace Forces.

Citation. Mamaraev R.M. Religious and Political Attitudes in the Mass Consciousness of Dagestan Youth. Vestnik Volgogradskogo gosudarstvennogo universiteta. Seriya 4, Istoriya. Regionovedenie. Mezhdunarodnye otnosheniya [Science Journal of Volgograd State University. History. Area Studies. International Relations], 2018, vol. 23, no. 4, pp. 159-175. (in Russian). DOI: https://doi.org/10.15688/jvolsu4.2018.4.14
\end{abstract}

УДК 32.019 .52

ББК 66.3(2Рос)

Дата поступления статьи: 20.10.2017

Дата принятия статьи: 10.04.2018

\section{РЕЛИГИОЗНО-ПОЛИТИЧЕСКИЕ УСТАНОВКИ В МАССОВОМ СОЗНАНИИ ДАГЕСТАНСКОЙ МОЛОДЕЖИ ${ }^{1}$}

\author{
Руслан Магомедсаламович Мамараев \\ Институт истории, археологии и этнографии ДНЦ РАН, г. Махачкала, Российская Федерация
}

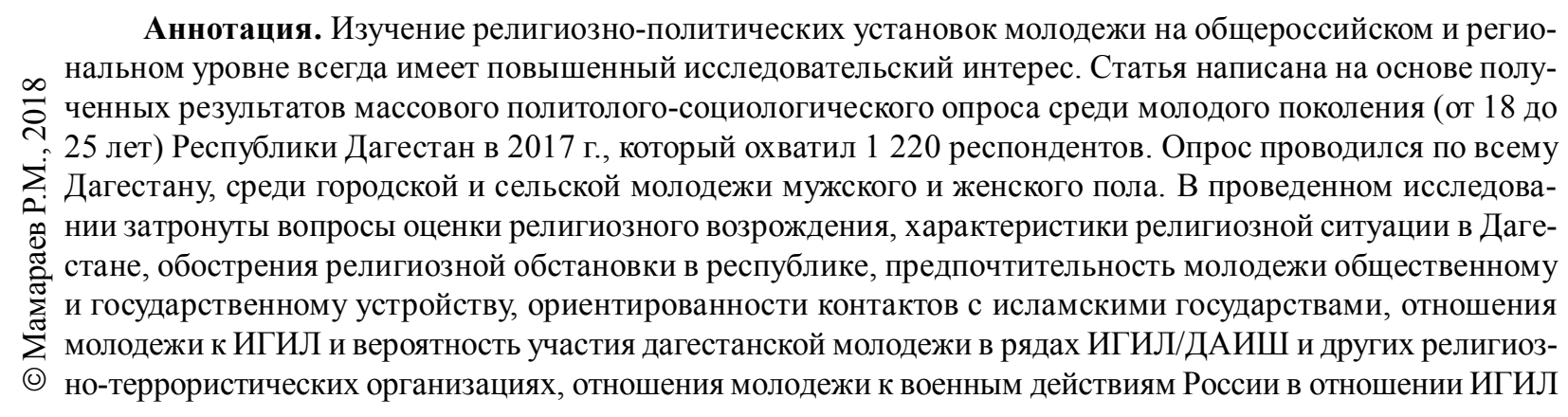


в Сирии, источников получения религиозной информации, отражения религиозного компонента на межнациональную сферу.

Ключевые слова: ислам, шариат, общество, терроризм, Ближний Восток, ВКС РФ.

Цитирование. Мамараев Р. М. Религиозно-политические установки в массовом сознании дагестанской молодежи // Вестник Волгоградского государственного университета. Серия 4, История. Регионоведение. Международные отношения. - 2018. - Т. 23, № 4. - С. 159-175. - DOI: https://doi.org/10.15688/jvolsu4.2018.4.14

\section{Введение}

Распространение экстримистских религиозно-политических идей, организаций и религиозно-террористических актов в мире, нестабильная геополитическая ситуация на Ближнем Востоке, деятельность запрещенной в России самой агрессивной на сегодняшний день религиозно-террористической организации ИГИЛ/ ДАИШ, прикрывающейся исламским вероучением, нахождение в ее рядах выходцев из Северного Кавказа, недостаточная изученность проблематики религиозно-политических установок в массовом сознании дагестанской молодежи с момента прокатившихся народных волнений и революций в арабо-мусульманском мире и образования на Ближнем Востоке агрессивной религиозно-террористической группировки ИГИЛ/ДАИШ актуализировали и определили выбор проведения данного массового политическо-социологического исследования среди дагестанской молодежи с целью выявления крайних религиозно-политических ориентаций, если такие имеют место быть.

\section{Методы}

В данном исследовании использован социологический метод исследования - анкетирование. В политологии социологические методы получили свое распространение. На их основе сложилась прикладная политология. Таким образом, предполагаемый проект через прикладное массовое политолого-социологическое исследование позволит изучить религиозно-политические установки в массовом сознании молодежи.

Начиная с конца XX в. проблема религиозно-политического экстремизма и терроризма в исламе приобретает важное значение для мирового сообщества, так как она затрагивает практически все страны мира. На сегодняшний день учеными во многих странах мира активно изучается данное опасное для мирового сообщества явление $[4 ; 5 ; 7 ; 9-11 ; 13 ; 15$; $16 ; 18 ; 19 ; 21 ; 23 ; 25-27 ; 29 ; 30 ; 32 ; 33 ; 36-46]$. Для России эта проблема имеет большое значение, так как Россия напрямую столкнулась с международным терроризмом на своей территории и сталкивается с ним у своих границ $[1-3 ; 6 ; 8 ; 12 ; 14 ; 17 ; 20 ; 22 ; 24 ; 28 ; 31]$.

\section{Анализ}

\section{Оценка молодежью} религиозной ситуации

в современном дагестанском обществе

С 80-90-х гг. и до настоящего времени в мире наблюдается активный рост радикальных религиозных течений, прикрывающихся исламским вероучением. Данные течения занимают антагонистские позиции по отношению к собственным правительствам и придерживаются крайне антизападных, а до распада СССР и антисоветских взглядов. В конце 80-х гг. во множестве мусульманских стран проявляется политический ислам в крайней радикальной форме, и Россия тут не стала исключением. Распад СССР, открытие границ, образовавшийся идеологический кризис способствовали бурному религиозному подъему в России среди населения и попадание в страну извне идей политизированного ислама с крайними формами проявления. Проявление крайних форм политического ислама на Северном Кавказе совпадает с волной радикализации ислама в мире. Группировки, развернувшие свою деструктивную деятельность на территории России и объявившие себя приверженцами фундаментального ислама, превратились в серьезную силу, которая дестабилизирует религиозно-политическую ситуацию в стране.

Таким образом, обозначенный в перестроечный период религиозный подъем в России имел не только позитивные, но и негатив- 
Р.М. Мамараев. Религиозно-политические установки в массовом сознании дагестанской молодежи

ные последствия, например, для дагестанского общества, связанные с распространением идеологии религиозно-политического экстремизма и терроризма. В этой связи в исследовании важным являлось установление и оценка последствий влияния религиозного возрождения на общественные сферы (табл. 1).

Приведенные результаты исследования свидетельствуют о том, что в массовом сознании дагестанских верующих превалирует позитивная оценка религиозного возрождения с мотивацией, во-первых, «улучшилось взаимопонимание между народами», во-вторых, «повысилась нравственность людей», в-третьих, «улучшились взаимоотношения и произошло единение мусульман», причем этих позиций в основном придерживаются подгруппы «убежденно верующих» и «верующих», в то время как «неверующие» и «убежденно неверующие» последствием религиозного возрождения считают «ухудшение отношений между народами», «появилось противостояние в исламе и между разными религиями», «появилось противостояние внутри представителей одного народа», причем доминирует суждение «религиозные деятели стали использовать религию в своих корыстных интересах». Последнюю позицию разделяет каждый девятый опрошен- ный среди «верующих» и каждый десятый среди них же позицию, что увеличение религиозного фактора в обществе вызвало противостояние в исламе и между разными религиями, что свидетельствует о наличии в массовом сознании определенного недовольства деятельностью религиозных организаций и духовных лиц.

В исследовании религиозного сознания и вытекающего из него религиозного поведения важным является выявление существующей в массовом сознании дагестанского общества характеристики религиозной ситуации в Дагестане (см. табл. 2).

По результатам проведенного исследования превалирует суждение «мирная, но с некоторыми моментами сохранения напряженности во взаимоотношениях между верующими» - 44,6 \%, которого придерживаются каждый второй опрошенный по всему массиву, причем доля таковых равномерно распределилась в подгруппах «убежденно верующих», «верующих» и «колеблющихся»; меньше всего таковых в подгруппе «убежденно неверующих», которым ближе позиция «напряженная» и «конфликтная». Обращает на себя внимание позиция молодежи, которая оценивает религиозную ситуацию в республике как «напряженную» - 32 \% (2-е ранговое место по

Таблийа 1

\begin{tabular}{|c|c|c|c|c|c|c|}
\hline \multirow{2}{*}{$\begin{array}{c}\text { Как Вы считаете, какое влияние } \\
\text { возрождение религии оказало } \\
\text { на развитие отношений } \\
\text { в дагестанском обществе? }\end{array}$} & \multicolumn{6}{|c|}{ Массив респондентов } \\
\hline & $\begin{array}{c}\text { Да, я убеж- } \\
\text { денно ве- } \\
\text { рующий }\end{array}$ & $\begin{array}{l}\text { Да, я ве- } \\
\text { рующий }\end{array}$ & $\begin{array}{l}\text { Я колеб- } \\
\text { лющийся }\end{array}$ & $\begin{array}{l}\text { Я неве- } \\
\text { рующий }\end{array}$ & $\begin{array}{c}\text { Я убеж- } \\
\text { денно не- } \\
\text { верующий }\end{array}$ & Итого \\
\hline $\begin{array}{l}\text { Положительное, так как улучшилось взаимо- } \\
\text { понимание между народами, \% }\end{array}$ & 25,4 & 17 & 12 & 10,6 & 0 & 18,1 \\
\hline $\begin{array}{l}\text { Положительное, так как повысилась нравст- } \\
\text { венность людей, \% }\end{array}$ & 22,1 & 17,4 & 9,9 & 9,1 & 2,8 & 17,4 \\
\hline $\begin{array}{l}\text { Положительное, так как улучшились взаимо- } \\
\text { отношения между представителями разных } \\
\text { религий, \% }\end{array}$ & 7,9 & 7,2 & 0,7 & 9,1 & 0 & 6,8 \\
\hline $\begin{array}{l}\text { Положительное, так как улучшились взаимоот- } \\
\text { ношения и произошло единение мусульман, \% }\end{array}$ & 17,3 & 12,4 & 10,5 & 3 & 0 & 12,8 \\
\hline $\begin{array}{l}\text { Отрицательное, так как ухудшились отноше- } \\
\text { ния между народами, \% }\end{array}$ & 2 & 3,5 & 6,3 & 4,5 & 13,9 & 4,7 \\
\hline $\begin{array}{l}\text { Отрицательное, так как появилось противо- } \\
\text { стояние в исламе и между разными религия- } \\
\text { ми, \% }\end{array}$ & 4 & 9,9 & 14,1 & 18,2 & 30,5 & 9,2 \\
\hline $\begin{array}{l}\text { Отрицательное, так как появилось противо- } \\
\text { стояние внутри представителей одного наро- } \\
\text { да, \% }\end{array}$ & 3,5 & 6,6 & 11,3 & 10,6 & 16,7 & 6,3 \\
\hline $\begin{array}{l}\text { Отрицательное, так как религиозные деятели } \\
\text { стали использовать религию в своих корыст- } \\
\text { ных интересах, \% }\end{array}$ & 8,4 & 10,9 & 16,2 & 21,2 & 33,3 & 11,2 \\
\hline Затрудняюсь ответить, \% & 9,4 & 15 & 19 & 13,6 & 2,8 & 13,4 \\
\hline Итого & 24 & 64,6 & 7,1 & 3 & 1,3 & 100 \\
\hline
\end{tabular}




\begin{tabular}{|c|c|c|c|c|c|}
\hline \multirow[b]{2}{*}{$\begin{array}{c}\text { Массив } \\
\text { респондентов }\end{array}$} & \multicolumn{5}{|c|}{ Как Вы оцениваете религиозную ситуацию в Дагестане? } \\
\hline & Напряженная, \% & Конфликтная, \% & Мирная, \% & $\begin{array}{c}\text { Мирная, но с некоторыми моментами } \\
\text { сохранения напряженности во взаи- } \\
\text { моотношениях между верующими, \% }\end{array}$ & Другое, \% \\
\hline $\begin{array}{l}\text { Да, я убежденно } \\
\text { верующий }\end{array}$ & 33,4 & 12,6 & 10,2 & 43 & 0,7 \\
\hline Да, я верующий & 31,3 & 12,9 & 8,8 & 46,1 & 0,9 \\
\hline Я колеблющийся & 29,9 & 17,2 & 9,2 & 42,5 & 1,1 \\
\hline Я неверующий & 38,9 & 2,8 & 8,3 & 38,9 & 11,1 \\
\hline $\begin{array}{l}\text { Я убежденно } \\
\text { неверующий }\end{array}$ & 31,2 & 31,2 & 6,2 & 25 & 6,2 \\
\hline Итого & 32 & 13,1 & 9,1 & 44,6 & 1,2 \\
\hline
\end{tabular}

всему массиву), причем доля таковых, по сравнению с другими подгруппами, заметно больше в подгруппе «неверующих». Однако следует отметить, что такая позиция характерна для молодежи независимо от типа религиозности. 3-е место занимает позиция, оценивающая религиозную ситуацию в республике как «конфликтная» - 13,1 \%, которая выражена у самоидентифицирующихся как «колеблющиеся» и «убежденно неверующие».

Далее в исследовании был задан вопрос, позволяющий выявить факторы обострения религиозной обстановки в Республике Дагестан (табл. 3).

Полученные результаты показывают, что, по мнению каждого второго, возникновению напряженности в религиозных отношениях между дагестанскими верующими способствует «распространение новых, чуждых традиционному исламу религиозных течений»49,8 \% (1-е ранговое место), причем его придерживаются больше половины опрошенных в подмассивах «убежденно верующих» и «верующих», каждый третий опрошенный среди «колеблющихся» и «убежденно неверующих». 2-е ранговое место с большим разрывом занимает суждение «деятельность политических партий и лидеров, использующих религиозные чувства населения в своих узко политических целях» - 20,2 \%, которого придерживается каждый четвертый в подгруппе «убежденно верующих», каждый пятый в подгруппах «верующих» и «колеблющихся». На 3-м месте находится суждение «стремление исламских организаций на исключительное положение в дагестанском обществе» 13,7 \%, которого придерживается каждый третий опрошенный из «колеблющихся», «неверующих» и «убежденно неверующих», и доля таковых в подгруппах «убежденно верующих» и «верующих» в 3 раза меньше. Далее следует позиция «борьба и амбиции духовных лидеров (имамов, священников) за сферу влияния» (12,8 \%), которая близка каждому девятому опрошенному по всему массиву, а по подмассивам ее придерживается почти равное количество опрошенных.

Полученные результаты показывают, что дагестанское молодое поколение в основной своей массе положительно оценивает и под-

Таблица 3

\begin{tabular}{|c|c|c|c|c|c|}
\hline \multirow[b]{2}{*}{$\begin{array}{c}\text { Массив } \\
\text { респондентов }\end{array}$} & \multicolumn{5}{|c|}{$\begin{array}{l}\text { Как Вы думаете, что приводит к возникновению напряженности в религиозных отношениях } \\
\text { между дагестанскими верующими? }\end{array}$} \\
\hline & $\begin{array}{c}\text { Распространение } \\
\text { новых, чуждых } \\
\text { традиционному } \\
\text { исламу религиоз- } \\
\text { ных течений, \% }\end{array}$ & $\begin{array}{c}\text { Деятельность политических } \\
\text { партий и лидеров, исполь- } \\
\text { зующих религиозные чув- } \\
\text { ства населения в своих узко } \\
\text { политических целях, \% }\end{array}$ & $\begin{array}{l}\text { Стремление ислам- } \\
\text { ских организаций на } \\
\text { исключительное по- } \\
\text { ложение в дагестан- } \\
\text { ском обществе, \% }\end{array}$ & $\begin{array}{c}\text { Борьба и амбиции } \\
\text { духовных лиде- } \\
\text { ров (имамов, } \\
\text { священников) за } \\
\text { сферу влияния, \% }\end{array}$ & Другое, \% \\
\hline $\begin{array}{l}\text { Да, я убежденно } \\
\text { верующий }\end{array}$ & 52,3 & 23,8 & 9,1 & 10,6 & 4,2 \\
\hline Да, я верующий & 51,2 & 19,5 & 12,8 & 13,4 & 3,1 \\
\hline Я колеблющийся & 39,5 & 19,3 & 26,9 & 13,5 & 0,8 \\
\hline Я неверующий & 27,6 & 17 & 29,8 & 12,8 & 12,8 \\
\hline $\begin{array}{l}\text { Я убежденно } \\
\text { неверующий }\end{array}$ & 41,7 & 8,3 & 29,2 & 16,7 & 4,1 \\
\hline Итого & 49,8 & 20,2 & 13,7 & 12,8 & 3,5 \\
\hline
\end{tabular}


P.М. Мамараев. Религиозно-политические установки в массовом сознании дагестанской молодежи

держивает религиозный подъем в республике, начиная с постсоветского периода, так как он стал залогом стабильности, консолидации и повышения нравственности в обществе на межнациональном и внутрирелигиозном уровне. При этом молодежь осознает и отрицательную сторону данного явления, которая связана с образованием напряженности между верующими, исповедующими исламское вероучение, и на межрелигиозном уровне. Также молодежь выделяет такой отрицательный факт, связанный с религиозным бумом, как использование религии в своих корыстных целях определенными религиозными кругами. Данная позиция связана с интенсивностью контактов религиозных и светских учреждений, которые, на первый взгляд, не носят деструктивный характер [34, с. 211-217], но в реальности стремление представителей дагестанского духовенства влиять на принятие решений в той или иной сфере, их вмешательство в кадровые, земельные, национальные и т. д. вопросы [35], представляется недопустимым, так как это не относится к их компетенции и сфере деятельности.

Делая выводы по данному блоку вопросов, можно сказать, что в большинстве своем дагестанская молодежь оценивает религиозную обстановку в республике как мирную. Однако она допускает напряженность, которая в первую очередь связана с распространением до этого неведомых, чуждых религиозных идей, которые стали проникать в республику в тяжелый для страны постсоветский период, в период децентрализации власти в стране, что привело к распространению в стране под ширмой ислама радикализма и терроризма. При этом молодые респонденты отмечают и субъективный внутренний фактор религиозной напряженности, связанный с деятельностью религиозных лидеров, которая способствует ухудшению религиозных отношений в Дагестане.

Осознание и понимание дагестанской молодежью происходящих религиозных процессов в республике, разграничение деструктивных внешних и внутренних факторов говорит о зрелой оценке молодежью религиозной ситуации в Республике Дагестан, что должно сыграть свою положительную роль в дальнейшем общественно-политическом развитии респуб- лики, так как данная молодежь рано или поздно придет на смену нынешнему поколению.

\section{Общественно-политическая ориентированность дагестанской молодежи}

Одним из основных факторов, влияющих на современное состояние и будущее развитие северокавказского общества, является процесс политизации и радикализации ислама в регионе. От стремительности и направления его развития будет зависеть по светскому или религиозному пути будут в дальнейшем развиваться республики Северного Кавказа.

С распадом Советского Союза новыми объектами геополитического влияния со стороны арабо-мусульманского мира стали мусульманские регионы России и новообразовавшиеся независимые республики бывшего Советского Союза, исповедующие ислам. В данных регионах стали пересекаться экономические и политические интересы основных участников мировой политики. Используя религиозный подъем в данных регионах, арабо-мусульманский мир начал интенсивно разворачивать свою деятельность на новых для них геополитически и экономически важных мусульманских территориях, поддерживая процесс активизации роли исламского фактора в социально-политической сфере, вызывая религиозный бум, стремясь тем самым распространить на них зону своего влияния, что не могло не вызвать обеспокоенность российских властей. Свою знаковую роль в данный процесс внесла конфликтная ситуация на Северном Кавказе.

Опасение исламизации молодежи заключается в ее повышенном уровне восприимчивости и подверженности влияния, с учетом юношеского максимализма. Одностороннее религиозное воспитание и образование может привести к поколению, которое будет ориентировано на строительство общественно-политической жизни, опираясь на религиозные принципы. Если еще данное поколение попадет под влияние и зависимость внешних деструктивных сил, то очевидна доля вероятности негативных последствий.

По этой причине в установлении доминирующих в массовом сознании дагестанской 


\section{ПОЛИТИЧЕСКИЕ НАУКИ И РЕГИОНОВЕДЕНИЕ}

молодежи религиозно-политических установок важным было выявление отношения молодежи к обществу, в котором они хотели бы проживать (табл. 4).

Результаты ответов на данный вопрос показывают, что больше половины опрошенных ориентированы на проживание «в светском государстве, со свободой вероисповедания», причем данная позиция ярко выражена во всех подгруппах, и 1-е ранговое место данная позиция занимает в подгруппах «верующий», «колеблющийся», «неверующий»; при этом обращает на себя внимание позиция «убежденно верующих», у которых на 1-м месте находится суждение «в исламском, по законам шариата» (каждый второй опрошенный), данная позиция также выражена у «верующих» (каждый четвертый опрошенный). С учетом типа религиозности вполне понятна ориентация «неверующих» и «убежденно неверующих», которые предпочитают проживать «в светском, атеистическом государстве».

Установление предпочтения опрошенных к общественному устройству предполагает выявление отношения опрошенных к государственному устройству (табл. 5).

Как можно увидеть, по всему массиву опрошенных, дагестанская молодежь предпочтение отдает «светскому Дагестану со свободой вероисповедания» (каждый третий опрошенный по всему массиву), однако с небольшой разницей на 2-м месте находится суждение, «если Дагестан станет исламской республикой, живущей по законам шариата, то это приведет к справедливости в республике, улучшению жизни людей и религиозной стабильности и т. д.», его придерживается каждый третий опрошенный среди «убежденно верующих» и каждый пятый опрошенный среди «верующих» и статистически незначимая доля в других подгруппах. Далее 3-е место по всему массиву занимает позиция ориентированных на исламскую республику, живущих по законам шариата с мотивацией «я верующий», причем их доля больше в подгруппе «убежденно верующих» (каждый третий опрошенный). По данному вопросу можно заключить, что молодежь хочет жить в светском государстве со

Таблица 4

\begin{tabular}{|l|c|c|c|c|c|}
\hline \multirow{2}{*}{$\begin{array}{c}\text { Массив } \\
\text { респондентов }\end{array}$} & \multicolumn{5}{|c|}{ В каком государстве Вы хотели бы жить? } \\
\cline { 2 - 6 } & $\begin{array}{c}\text { В исламском, по } \\
\text { законам шариата, \% }\end{array}$ & $\begin{array}{c}\text { В светском, атеи- } \\
\text { стическом, \% }\end{array}$ & $\begin{array}{c}\text { В светском, со свободой } \\
\text { вероисповедания, \% }\end{array}$ & Безразлично, \% & $\begin{array}{c}\text { Затрудняюсь } \\
\text { ответить, \% }\end{array}$ \\
\hline $\begin{array}{l}\text { Да, я убежденно } \\
\text { верующий }\end{array}$ & 46,1 & 0 & 42 & 3,4 & 8,5 \\
\hline Да, я верующий & 25,0 & 0,8 & 58,9 & 4,9 & 10,4 \\
\hline Я колеблющийся & 5,7 & 6,9 & 63,2 & 12,6 & 11,5 \\
\hline Я неверующий & 5,6 & 22,2 & 55,6 & 0 & 16,7 \\
\hline $\begin{array}{l}\text { Я убежденно } \\
\text { неверующий }\end{array}$ & 0 & 56,2 & 43,8 & 0 & 0 \\
\hline \multicolumn{1}{|l|}{ Итого } & $\mathbf{2 7 , 8}$ & $\mathbf{2 , 4}$ & $\mathbf{5 4 , 8}$ & $\mathbf{4 , 9}$ & $\mathbf{1 0 , 1}$ \\
\hline
\end{tabular}

Таблииа 5

\begin{tabular}{|l|c|c|c|c|c|c|}
\hline \multicolumn{1}{|c|}{$\begin{array}{c}\text { Хотите ли Вы, чтоб Дагестан стал } \\
\text { исламской республикой, } \\
\text { живущей по законам шариата? }\end{array}$} & $\begin{array}{c}\text { Массив респондентов } \\
\text { жа, я убе- } \\
\text { верующий }\end{array}$ & $\begin{array}{c}\text { Да, я ве- } \\
\text { рующий }\end{array}$ & $\begin{array}{c}\text { Я колеб- } \\
\text { лющийся }\end{array}$ & $\begin{array}{c}\text { Я неве- } \\
\text { рующий }\end{array}$ & $\begin{array}{c}\text { Я убеж- } \\
\text { денно не-- } \\
\text { верующий }\end{array}$ & Итого \\
\hline Да, так как я верующий, \% & 31,0 & 15,1 & 0,9 & 0 & 0 & $\mathbf{1 7 , 5}$ \\
\hline $\begin{array}{l}\text { Да, это приведет к справедливости в республи- } \\
\text { ке и улучшению жизни людей, религиозной } \\
\text { стабильности и т. д., \% }\end{array}$ & 32,2 & 20,6 & 6,3 & 2,2 & 0 & $\mathbf{2 1 , 7}$ \\
\hline $\begin{array}{l}\text { Нет, от этого ничего не изменится, станет хуже, } \\
\text { будет внутрирелигиозная борьба за власть, де- } \\
\text { градация, \% }\end{array}$ & 10,7 & 17,6 & 20,9 & 13,0 & 4,8 & $\mathbf{1 5 , 8}$ \\
\hline $\begin{array}{l}\text { Нет, я хочу жить в светском Дагестане, со сво- } \\
\text { бодой вероисповедания, \% }\end{array}$ & 16 & 33 & 46,3 & 54,3 & 38,1 & $\mathbf{3 0 , 3}$ \\
\hline $\begin{array}{l}\text { Нет, я хочу жить в светском атеистическом Да- } \\
\text { гестане, \% }\end{array}$ & 0,5 & 0,4 & 5,5 & 21,7 & 42,8 & $\mathbf{2 , 0}$ \\
\hline Безразлично, \% & 1,0 & 2,7 & 8,2 & 2,2 & 9,5 & $\mathbf{2 , 7}$ \\
\hline Затрудняюсь ответить, \% & 8,6 & 10,6 & 11,8 & 6,5 & 4,8 & $\mathbf{1 0 , 0}$ \\
\hline
\end{tabular}


свободой вероисповедания, но из-за того что светская государственная система общественного регулирования в Республике Дагестан неэффективна, молодежь, исходя из юношеского максимализма и чувства справедливости, пытается найти в религии честность, справедливость, порядок, духовно-нравственное оздоровление общества.

Рост значимости религиозного компонента в республике, возможность выезжать на учебу, работу и т. д. за пределы России предполагает установление ориентированности на поддержание разного уровня контактов с исламскими государствами (табл. 6).

Полученные результаты исследования показывают, что опрошенные независимо от типа религиозности ориентированы на поддержание и укрепление связей со всеми государствами «независимо от их религиозной, культурной, политической, экономической принадлежности» (больше половины опрошенных по всему массиву), при этом суждения «исключительно с мусульманскими государствами и регионами» и «только с теми, с которыми выгодно религиозное сотрудничество» отметила небольшая доля опрошенных.

При исследовании религиозного сознания и поведения очень важным является выявление информативных источников получения интересующей молодое поколение информации. Общедоступная всемирная сеть имеет не только положительные, но и отрицательные последствия, ибо еще неокрепшее сознание подрастающего поколения способно как губ- ка впитывать не только необходимую, но и потенциально опасную для них информацию. Различные негативные религиозно-политические идеи могли проникать на территорию России не физическим способом, посредством различных проповедников, эмиссаров и т. д., а виртуальным способом, через глобальную сеть Интернет. Таким образом, в исследовании респондентам был задан вопрос, позволяющий установить источники получения религиозной информации (см. табл. 7).

Таким образом, основными источниками информации для опрошенных являются: «общение с родными, друзьями, знакомыми» (1-е ранговое место), «проповеди религиозных лидеров (муфтий, мулла, преподаватель исламского учебного заведения)» (2-е ранговое место), причем их доля сравнительно больше в подгруппе «убежденно верующих», впрочем, как и среди предпочитающих «религиозные книги» (по всему массиву 3-е ранговое место) и «интернет-источники (ВКонтакте, Facebook», You Tube)» (по всему массиву 4-е ранговое место), в то время остальные информационные источники набрали менее $10 \%$. При этом каждый одиннадцатый опрошенный по всему массиву «мало интересуется религиозной тематикой». По всему массиву опрошенных доля «мало интересующихся религиозной тематикой» доминирует в подгруппах «колеблющихся», «неверующих» и «убежденно неверующих». Кроме того, мало интересны для опрошенных бумажные носители информации (книги, журналы, газеты), которые, следует

Таблица 6

\begin{tabular}{|c|c|c|c|c|c|c|}
\hline \multirow[b]{2}{*}{$\begin{array}{c}\text { Согласны ли Вы с тем, что Дагестан } \\
\text { должен укреплять связи... }\end{array}$} & \multicolumn{5}{|c|}{ Массив респондентов } & \multirow[b]{2}{*}{ Итого } \\
\hline & $\begin{array}{l}\text { Да, я убе- } \\
\text { жденно } \\
\text { верующий }\end{array}$ & $\begin{array}{l}\text { Да, я ве- } \\
\text { рующий }\end{array}$ & $\begin{array}{l}\text { Я колеб- } \\
\text { лющийся }\end{array}$ & $\begin{array}{l}\text { Я неве- } \\
\text { рующий }\end{array}$ & $\begin{array}{c}\text { Я убеж- } \\
\text { денно не- } \\
\text { верующий }\end{array}$ & \\
\hline $\begin{array}{l}\text { Исключительно с мусульманскими государ- } \\
\text { ствами и регионами, \% }\end{array}$ & 12,8 & 6,3 & 2,2 & 0 & 0 & 7,8 \\
\hline $\begin{array}{l}\text { Со всеми государствами независимо от их ре- } \\
\text { лигиозной, культурной, политической, эконо- } \\
\text { мической принадлежности, \% }\end{array}$ & 40,3 & 56,1 & 43,5 & 52,1 & 42,3 & 52,5 \\
\hline $\begin{array}{l}\text { Только с теми, с которыми выгодно экономи- } \\
\text { ческое сотрудничество, } \%\end{array}$ & 11,7 & 13,2 & 15,2 & 18,7 & 23,1 & 13,7 \\
\hline $\begin{array}{l}\text { Только с теми, с которыми выгодно религи- } \\
\text { озное сотрудничество, \% }\end{array}$ & 8,5 & 5,1 & 5,8 & 0 & 0 & 6,1 \\
\hline $\begin{array}{l}\text { Только с теми, с которыми выгодно культур- } \\
\text { ное сотрудничество, \% }\end{array}$ & 19,2 & 8,4 & 17,4 & 12,5 & 11,5 & 8,7 \\
\hline $\begin{array}{l}\text { Только с теми, с которыми выгодно полити- } \\
\text { ческое сотрудничество, } \%\end{array}$ & 5,7 & 9,2 & 14,5 & 10,4 & 23,1 & 9,2 \\
\hline Другое, $\%$ & 1,8 & 1,7 & 1,4 & 6,2 & 0 & 2 \\
\hline
\end{tabular}


Таблица 7

\begin{tabular}{|c|c|c|c|c|c|c|}
\hline \multirow{2}{*}{$\begin{array}{c}\text { Скажите, пожалуйста, из каких } \\
\text { источников в наибольшей степени } \\
\text { Вы получаете интересующую } \\
\text { Вас информацию о религии? }\end{array}$} & \multicolumn{5}{|c|}{ Массив респондентов } & \multirow[b]{2}{*}{ Итого } \\
\hline & $\begin{array}{l}\text { Да, я убеж- } \\
\text { денно ве- } \\
\text { рующий }\end{array}$ & $\begin{array}{l}\text { Да, я ве- } \\
\text { рующий }\end{array}$ & $\begin{array}{l}\text { Я колеб- } \\
\text { лющийся }\end{array}$ & $\begin{array}{l}\text { Я неве- } \\
\text { рующий }\end{array}$ & $\begin{array}{c}\text { Я убеж- } \\
\text { денно не- } \\
\text { верующий }\end{array}$ & \\
\hline $\begin{array}{l}\text { Из религиозных газет и журналов, издаю- } \\
\text { щихся в Дагестане, \% }\end{array}$ & 8,3 & 7,1 & 2,4 & 1,8 & 0 & 7,0 \\
\hline $\begin{array}{l}\text { Из религиозных газет и журналов, издаю- } \\
\text { щихся за пределами Дагестана, \% }\end{array}$ & 1,2 & 1,1 & 0 & 0 & 0 & 1,0 \\
\hline $\begin{array}{l}\text { Из проповедей религиозных лидеров (муф- } \\
\text { тий, мулла, преподаватель исламского } \\
\text { учебного заведения), \% }\end{array}$ & 18,3 & 13,8 & 7,8 & 3,6 & 0 & 14,4 \\
\hline $\begin{array}{ll}\text { Из интернет-источников } & \text { (ВКонтакте, } \\
\text { Facebook, You Tube и т. д.), \% } & \end{array}$ & 12,0 & 12,1 & 17,3 & 12,5 & 8,7 & 12,3 \\
\hline $\begin{array}{l}\text { Из Приложений телефона (WhatsApp, Viber } \\
\text { и т. д.), \% }\end{array}$ & 3,6 & 5,3 & 5,4 & 5,3 & 4,3 & 4,8, \\
\hline Из религиозных телепередач, \% & 8,7 & 8,4 & 6,0 & 3,6 & 0 & 8,2 \\
\hline Из религиозных сайтов, \% & 5,7 & 5,1 & 2,4 & 0 & 0 & $\mathbf{5 , 0}$ \\
\hline Из религиозных книг, \% & 17,2 & 11,3 & 6,6 & 3,6 & 4,3 & 12,4 \\
\hline Из религиозных DVD-дисков, \% & 3,1 & 2,1 & 0,6 & 1,8 & 0 & 2,3 \\
\hline $\begin{array}{l}\text { Из общения с родными, друзьями, знако- } \\
\text { мыми, \% }\end{array}$ & 19,3 & 24,3 & 21 & 14,2 & 21,7 & 22,5 \\
\hline $\begin{array}{l}\text { Я мало интересуюсь религиозной темати- } \\
\text { кой, \% }\end{array}$ & 2,1 & 8,4 & 29,3 & 50 & 52,2 & 9,0 \\
\hline Другое, \% & 0,5 & 1,0 & 1,2 & 3,6 & 8,7 & 1,0 \\
\hline
\end{tabular}

отметить, имеются в большом количестве. На себя обращает внимание доля тех, кто обращается к «интернет-источникам», в которых большое количество радикальной и вербовочной составляющей. Тут стоить отметить, что постоянно растет объем передаваемой информации в Интернете, что свидетельствует об увеличении объема, скорости, масштабов распространения информации. Стоит добавить и то, что проведенное автором исследование в Дагестане в 2017 г. в рамках плановой научной работы показало, что каждый второй респондент ежедневно пользуется Интернетом.

Таким образом, по данному разделу можно сделать вывод, что несмотря на мощный религиозный подъем в Дагестане в постсоветский период, на высокую религиознополитическую активность арабо-мусульманского мира и попыток распространения своего влияния на регион, распространением деструктивных религиозно-политических идей, крайние радикальные религиозно-политические идеи не повлияли на религиозно-политические ориентации дагестанской молодежи. Молодежь Дагестана в большинстве своем остается приверженцем светского государственного устройства, со свободой вероисповедания; отдает предпочтение светскому
Дагестану со свободой вероисповедания, проявляя опасение в отношении того, что религиозный общественно-политический уклад в республике не приведет к оздоровлению в обществе, а только ухудшит религиозную ситуацию в республике, будет способствовать регрессу в обществе; внешнеполитически ориентирована на поддержание и укрепление связей со всеми государствами, независимо от их религиозной, культурной, политической, экономической принадлежности; основными источниками религиозной информации являются внутренние ресурсы; дагестанская молодежь четко отделяет культовую сферу от политической, экономической, культурной. Более того, им характерно ставить выше экономическую составляющую, над религиозной, культурной и политической.

При этом обращает на себя внимание позиция «убежденно верующих» и «верующих», которые составляют основную массу респондентов, у которых выражены ориентации на религиозно-политическое государственное устройство, в том числе и Республики Дагестан. Данные позиции связаны скорее не с религиозным фактором как таковым, а с внутренними проблемами, которые сложились и накопились в дагестанском обществе в постсоветский период. Данное суждение связа- 
P.M. Мамараев. Религиозно-политические установки в массовом сознании дагестанской молодежи

но с желанием данных категорий респондентов установления в республике религиозного общественно-политического устройства по причине того, что он верующий, которое у них не является доминирующей, и с тем, что у данных категорий лиц на низком уровне выражены позиции установления Республикой Дагестан связей исключительно с мусульманскими государствами и регионами, с которыми выгодно религиозное сотрудничество. А внутренние проблемы, вызывающие религиозно-политические ориентации, связаны со справедливостью в обществе; условиями жизни людей; общественной, религиозной, межнациональной стабильностью; с использованием религиозного фактора в своих корыстных целях определенными религиозными и политическими кругами, что не может не дестабилизировать общественную ситуацию; неэффективным государственным регулированием и налаживанием общественной жизни и т. д. Возможно, данные негативные общественные явления также способствуют поиску религиозной информации, ответов на интересующие вопросы в интернет-источниках, в которых также имеется достаточное количество негативной составляющей. Возможно, данная категория молодежи и хочет жить в светском государстве со свободой вероисповедания, но из-за того что светская государственная система общественного регулирования в Республике Дагестан неэффективна, молодежь пы- тается найти в религии решение проблем на микро- и макроуровне.

\section{Видение дагестанской молодежи современной религиозно-политической ситуации на Ближнем Востоке}

На сегодняшний день имеется большое количество религиозных террористических организаций, использующих исламское вероучение, которые представляют угрозу не только национальной безопасности России, но и всему миру. По этой причине важным является выявление отношения дагестанской молодежи к запрещенной в России самой агрессивной на сегодняшний день террористической организации ИГИЛ/ДАИШ (табл. 8).

По всему массиву опрошенных, независимо от типа религиозности в массовом сознании дагестанских верующих в отношении к так называемому «Исламскому государству» (ИГИЛ/ДАИШ) превалирует негативная оценка, потому что они, во-первых, «применяют насилие и жестокость, которые в исламе не поощряются (сжигание, казнь людей, независимо от религиозной принадлежности)», во-вторых, «не имеют ничего общего с исламом и исламскими ценностям», в-третьих, «под знаменем ислама зарабатывают деньги»; статистически небольшая доля опрошенных позитивно оценивают ИГИЛ с мотиваци-

Таблица 8

\begin{tabular}{|c|c|c|c|c|c|c|c|}
\hline \multirow[b]{2}{*}{$\begin{array}{c}\text { Массив рес- } \\
\text { пондентов }\end{array}$} & \multicolumn{7}{|c|}{$\begin{array}{c}\text { Как Вы оцениваете деятельность Исламского государства (ИГИЛ) в Сирии и Ираке? } \\
\text { (можно выбрать } 3 \text { варианта ответов) }\end{array}$} \\
\hline & $\begin{array}{c}\text { Положи- } \\
\text { тельно, они } \\
\text { защищают } \\
\text { основы ис- } \\
\text { ламской ре- } \\
\text { лигии (веро- } \\
\text { учение), \% } \\
\end{array}$ & $\begin{array}{c}\text { Положительно, пото- } \\
\text { му что они защищают } \\
\text { исламские ценности, } \\
\text { которые западное об- } \\
\text { щество оскорбляет } \\
\text { (карикатуры на проро- } \\
\text { ка и т. д.), \% } \\
\end{array}$ & $\begin{array}{c}\text { Положи- } \\
\text { тельно, они } \\
\text { стремятся } \\
\text { объединить } \\
\text { всех му- } \\
\text { сульман, \% }\end{array}$ & $\begin{array}{c}\text { Отрицательно, } \\
\text { они не имеют } \\
\text { ничего общего } \\
\text { с исламом и } \\
\text { исламскими } \\
\text { ценностями, \% }\end{array}$ & $\begin{array}{c}\text { Отрицательно, они при- } \\
\text { меняют насилие и жесто- } \\
\text { кость, которые в исламе } \\
\text { не поощряются (сжига- } \\
\text { ние, казнь людей, незави- } \\
\text { симо от религиозной } \\
\text { принадлежности), \% } \\
\end{array}$ & $\begin{array}{c}\text { Отрица- } \\
\text { тельно, они } \\
\text { под знаме- } \\
\text { нем ислама } \\
\text { зарабаты- } \\
\text { вают день- } \\
\text { ги, \% } \\
\end{array}$ & $\begin{array}{l}\text { Дру- } \\
\text { гое, } \\
\%\end{array}$ \\
\hline $\begin{array}{l}\text { Да, я убеж- } \\
\text { денно ве- } \\
\text { рующий }\end{array}$ & 3,3 & 3 & 2,3 & 27,4 & 37,7 & 22,5 & 3,8 \\
\hline $\begin{array}{l}\text { Да, я ве- } \\
\text { рующий }\end{array}$ & 1,7 & 2,7 & 1,9 & 27,4 & 41,3 & 22,8 & 2,2 \\
\hline $\begin{array}{l}\text { Я колеб- } \\
\text { лющийся }\end{array}$ & 1,3 & 2,6 & 0 & 26,7 & 42 & 24,8 & 2,6 \\
\hline $\begin{array}{l}\text { Я неве- } \\
\text { рующий }\end{array}$ & 0 & 3 & 0 & 22,4 & 46,2 & 25,4 & 3 \\
\hline $\begin{array}{l}\text { Я убеж- } \\
\text { денно не- } \\
\text { верующий }\end{array}$ & 0 & 0 & 2,9 & 26,5 & 44,1 & 23,5 & 2,9 \\
\hline Итого & 2 & 2,7 & 1,8 & 27,2 & 40,7 & 23 & 2,6 \\
\hline
\end{tabular}




\section{ПОЛИТИЧЕСКИЕ НАУКИ И РЕГИОНОВЕДЕНИЕ}

ей, что они защищают «основы исламской религии (вероучение)», «исламские ценности, которые западное общество оскорбляет (карикатуры на пророка и т. д.)» и «стремятся объединить всех мусульман».

Наряду с выявлением отношения к ИГИЛ, важным является выявление установок дагестанской молодежи на возможность участия в его рядах (табл. 9).

Результаты исследования констатируют доминирование позиции, что представители дагестанской молодежи не приняли бы участие в деятельности террористических организаций, использующих исламское вероучение, ибо, по их мнению, находящиеся в рядах данных организаций люди являются «террористами и убийцами», хотя статистически незначительная доля опрошенных считают, что они «отстаивают основы ислама» и, следовательно, они могут влиться в их ряды. В предыдущем вопросе «Как Вы оцениваете деятельность Исламского государства (ИГИЛ) в Сирии и Ираке?» такая же доля опрошенных положительно оценивала деятельность вышеперечисленных организаций с такой же мотивацией. Определенный интерес представляет категория «затруднившихся ответить», которые могут являться группой риска, причем больше всего выбравших данную пози- цию в подгруппах «убежденно верующих», «верующих» и «колеблющихся».

Из предыдущих двух вопросов логично вытекает вопрос «Как Вы относитесь к дагестанцам, которые находятся в рядах Аль-Каиды, ИГИЛа, Имарат Кавказа, Талибана, Хизбу-Тахрира и т. д.?» (табл. 10).

В ответах на данный поставленный перед респондентами вопрос по всему массиву больше половины опрошенных негативно настроены к дагестанцам, которые участвуют в террористической деятельности и влились в ряды ИГИЛ. Но при этом заставляет задуматься позиция каждого четвертого опрошенного по всему массиву, которые затруднились выразить свое отношение к данной террористической деятельности со стороны дагестанцев, причем доля таковых больше в подгруппах «убежденно верующих» и «верующих». Тут стоить отметить, что среди тех респондентов, которые дали свой вариант ответа, с сожалением отнеслись к данным людям, мотивируя это тем, что их могли на это сподвигнуть жизненные обстоятельства или их могли заманить в данные ряды обманным путем, играя на их религиозных чувствах. Кроме того, суждение «положительно» с мотивацией, что «они отстаивают основы ислама» набрало

Таблииа 9

\begin{tabular}{|c|c|c|c|c|c|}
\hline \multirow[b]{2}{*}{ Массив респондентов } & \multicolumn{5}{|c|}{$\begin{array}{c}\text { Вы бы сами приняли участие в деятельности исламских террористических организа- } \\
\text { ций (Аль-Каида, ИГИЛ, Имарат Кавказ, Талибан, Хизбу-Тахрир и т. д.)? }\end{array}$} \\
\hline & $\begin{array}{l}\text { Да, так как они } \\
\text { отстаивают ос- } \\
\text { новы ислама, \% }\end{array}$ & $\begin{array}{l}\text { Да, если мне } \\
\text { заплатят, \% }\end{array}$ & $\begin{array}{c}\text { Да, если меня } \\
\text { вынудят это сде- } \\
\text { лать, \% }\end{array}$ & $\begin{array}{l}\text { Нет, это террори- } \\
\text { сты и убийцы, \% }\end{array}$ & $\begin{array}{c}\text { Затрудняюсь } \\
\text { ответить, \% }\end{array}$ \\
\hline Да, я убежденно верующий & 3,1 & 0,3 & 0 & 83,3 & 13,3 \\
\hline Да, я верующий & 1,1 & 1,0 & 0,3 & 87,3 & 10,3 \\
\hline Я колеблющийся & 3,4 & 0 & 1,1 & 85,1 & 10,3 \\
\hline Я неверующий & 0 & 0 & 0 & 94,4 & 5,6 \\
\hline Я убежденно неверующий & 0 & 0 & 6,2 & 93,8 & 0 \\
\hline Иmого & 1,7 & 0,7 & $\mathbf{0 , 3}$ & 86,5 & 10,7 \\
\hline
\end{tabular}

Таблича 10

\begin{tabular}{|c|c|c|c|c|}
\hline \multirow[b]{2}{*}{ Массив респондентов } & \multicolumn{4}{|c|}{$\begin{array}{c}\text { Как Вы относитесь к дагестанцам, которые находятся в рядах Аль-Каиды, } \\
\text { ИГИЛа, Имарат Кавказа, Талибана, Хизбу-Тахрира и т. д.? }\end{array}$} \\
\hline & $\begin{array}{c}\text { Положительно, } \\
\text { так как они отстаива- } \\
\text { ют основы ислама, \% }\end{array}$ & $\begin{array}{c}\text { Отрицательно, так как это } \\
\text { бандиты, которые несут уг- } \\
\text { розу России и Дагестану, \% }\end{array}$ & $\begin{array}{l}\text { Затрудняюсь } \\
\text { ответить, \% }\end{array}$ & $\begin{array}{c}\text { Свой вари- } \\
\text { ант, \% }\end{array}$ \\
\hline Да, я убежденно верующий & 5,5 & 61,4 & 28 & 5,1 \\
\hline Да, я верующий & 2,5 & 67,4 & 26,3 & 3,8 \\
\hline Я колеблющийся & 2,3 & 70,1 & 21,8 & 5,7 \\
\hline Я неверующий & 0 & 86,1 & 11,1 & 2,8 \\
\hline Я убежденно неверующий & 0 & 93,8 & 0 & 6,2 \\
\hline Итого & 3,1 & 67 & 25,6 & 4,3 \\
\hline
\end{tabular}


статистически незначительную цифру, но больше всего выбравших данную позицию в подгруппе «убежденно верующих» и доля таковых в два раза меньше в подмассиве «верующих» и «колеблющихся».

С конца 2015 г. Российская Федерация начала военную операцию Воздушно-космических сил (ВКС) на территории Сирийской Арабской Республики, продиктованную появлением и распространением на Ближнем Востоке террористической организации «Исламское государство» (ИГИЛ/ДАИШ), которая несет угрозу не только всему Ближнему Востоку, но и всему миру. В ряды данной организации широко вовлекаются выходцы из республик бывшего СССР, а также российские граждане из Северного Кавказа. В этой связи был задан вопрос, позволяющий выявить отношение респондентов к военным действиям России в отношении ИГИЛ (табл. 11).

Полученные результаты исследования показывают, что каждый третий опрошенный по всему массиву поддерживает политику Российского государства в Сирии с мотивацией, что Россия «борется с террористами, которые угрожают России и Северному Кавказу», причем данная позиция ярко выражена во всех подгруппах и занимает 1-е ранговое место в подгруппах «верующих», «колеблющихся» и «убежденно неверующих». Вместе с тем каждый третий опрошенный по всему массиву затруднился выразить свое отношение к российской политике в Сирии, данная позиция 1-е ранговое место занимает в подгруппах «убежденно верующих», «колеблю- щихся». 3-е ранговое место занимает суждение «Россия поддерживает своего союзника и отстаивает свой престиж в международных отношениях, давая отпор США и Европе», которое ближе каждому четвертому опрошенному среди «колеблющихся» и «неверующих», каждому пятому опрошенному среди «верующих» и меньше всего таковых среди «убежденно неверующих». По отрицательным позициям, по сравнению с остальными подгруппами, относительную активность показывают опрошенные, самоидентифицирующиеся как «убежденно верующие», придерживаясь негативной оценки: «Россия поддерживает шиитов, а не суннитов», «Россия поддерживает кровавый режим Башара Асада» и «тратятся деньги, надо решать проблемы внутри страны». Также определенный интерес представляет категория «затруднившихся ответить», в которой может скрываться отрицательное отношение к политике России в Сирии, но при этом стоить отметить, что данный вариант могла выбирать и та молодежь, которая аполитична, мало интересуется/которой неинтересна внешняя политика страны и международные отношения, которая не совсем ясно понимает сложившуюся геополитическую, международную ситуацию вокруг Сирии и на Ближнем Востоке, которая сосредоточена на своих собственных проблемах.

Полученные результаты исследования по данному блоку вопросов говорят, что в массовом сознании дагестанских верующих в отношении к так называемому «Исламскому государству» (ИГИЛ/ДАИШ) независимо от

Таблииа 11

\begin{tabular}{|c|c|c|c|c|c|c|}
\hline \multirow[b]{2}{*}{$\begin{array}{c}\text { Массив } \\
\text { респондентов }\end{array}$} & \multicolumn{6}{|c|}{ Поддерживаете ли Вы политику России в Сирии? } \\
\hline & $\begin{array}{c}\text { Нет, так как } \\
\text { Россия под- } \\
\text { держивает } \\
\text { шиитов, а не } \\
\text { суннитов, \% }\end{array}$ & $\begin{array}{c}\text { Нет, так как } \\
\text { Россия под- } \\
\text { держивает } \\
\text { кровавый ре- } \\
\text { жим Башара } \\
\text { Асада, \% }\end{array}$ & $\begin{array}{l}\text { Нет, так как } \\
\text { тратятся } \\
\text { деньги, надо } \\
\text { решать про- } \\
\text { блемы внутри } \\
\text { страны, \% } \\
\end{array}$ & $\begin{array}{c}\text { Да, так как Россия под- } \\
\text { держивает своего союз- } \\
\text { ника и отстаивает свой } \\
\text { престиж в международ- } \\
\text { ных отношениях, давая } \\
\text { отпор США и Европе, \% }\end{array}$ & $\begin{array}{c}\text { Да, так как Россия } \\
\text { борется с терро- } \\
\text { ристами, которые } \\
\text { угрожают России } \\
\text { и Северному Кав- } \\
\text { казу, \% }\end{array}$ & $\begin{array}{c}\text { Затруд- } \\
\text { няюсь } \\
\text { ответить, } \\
\text { \% }\end{array}$ \\
\hline $\begin{array}{l}\text { Да, я убежден- } \\
\text { но верующий }\end{array}$ & 6,5 & 7,5 & 7,2 & 14,7 & 30,7 & 33,4 \\
\hline $\begin{array}{l}\text { Да, я верую- } \\
\text { щий }\end{array}$ & 4,6 & 2,8 & 8,2 & 19,7 & 33,2 & 31,5 \\
\hline $\begin{array}{l}\text { Я колеблю- } \\
\text { щийся }\end{array}$ & 1,1 & 5,7 & 5,7 & 23,0 & 32,2 & 32,2 \\
\hline $\begin{array}{l}\text { Я } \text { неверую- } \\
\text { щий }\end{array}$ & 0 & 0 & 11,1 & 22,2 & 44,4 & 22,2 \\
\hline $\begin{array}{l}\text { Я убежденно } \\
\text { неверующий }\end{array}$ & 0 & 0 & 25,0 & 12,5 & 37,5 & 25,0 \\
\hline Иmого & 4,6 & 4 & 8,1 & 18,7 & 33 & 31,6 \\
\hline
\end{tabular}


типа религиозности превалирует негативная оценка, с мотивировкой, что данная организация не имеет никакого отношения к исламу и исламским ценностям, которые использует в своих корыстных целях, применяя террор. По этой причине у представителей дагестанской молодежи доминирует категоричная позиция в отношении гипотетического участия в деятельности террористических организаций, использующих исламское вероучение, и, соответственно, в основной своей массе они негативно настроены к дагестанцам, которые принимают участие в террористических организациях, в том числе и ИГИЛ. Также дагестанская молодежь в большинстве своем поддерживает политику Российского государства в Сирии с мотивацией, что Россия борется с террористами, которые угрожают России и Северному Кавказу соответственно. Также стоит сказать, что не оправдались опасения, связанные с волной недовольства и возмущения по поводу политической и военной позиции российских властей в Сирии из-за внутриконфессиональных различий и противостояния в исламе между суннитами и шиитами.

Помимо этого стоит отметить, что статистически низкий процент опрошенных позитивно оценивают ИГИЛ с мотивацией, что они защищают исламскую религию и стремятся объединить всех мусульман; допускают вероятность участия в религиозно-террористических организациях, использующих исламское вероучение, в основном по религиозным и экономическим мотивам; положительно относятся к дагестанцам в рядах различных религиозно-террористических организаций; не поддерживают политику России в Сирии, что в первую очередь связано с экономическим фактором. Но больше всего определенный интерес представляет категория затруднившихся ответить на данные поставленные вопросы, которые составляют более значительную цифру и могут являться группой риска.

Данные позиции, возможно, вызваны имеющимися у данной категории респондентов определенных религиозно-политических убеждений по данным вопросам или аполитичностью, отсутствием понимания геополитических и международных процессов, озабоченностью своими проблемами или предположением респондентов о случайном ха- рактере попадания дагестанцев в ряды религиозно-террористических организаций, изза жизненных обстоятельств или обмана. Возможно, данные позиции вызваны имеющимся комплексом проблем в современном дагестанском обществе, то есть внутренними, а не внешними и фанатично-идеологическими причинами.

\section{Результаты}

Подводя общий итог представленного исследования, можно сказать: 1. Доминирующую массу молодых респондентов составляет верующая и убежденно верующая молодежь. 2. Неоднозначная оценка возрождения и увеличения религиозного фактора в общественной жизни, начиная с постсоветского периода. Основная масса верующей молодежи положительно оценивают возрождение религии в общественной жизни, но есть и те, кто отрицательно оценивают данное явление и не довольны деятельностью религиозных организаций и духовных лиц. 3. Религиозная ситуация в Республике Дагестан оценивается как мирная, но с элементами напряженности. 4. Факторами обострения религиозной обстановки в Дагестане, по мнению молодежи, являются распространение чуждых традиционному исламу религиозных идей и деятельность политических партий и отдельных лиц, которые используют религиозный потенциал в своих корыстных целях. 5. Основными источниками информации для молодежи являются близкое окружение, религиозные деятели, религиозная литература и интернет-источники. 6. Доминирующая часть молодежи желает жить в светском обществе, со свободой вероисповедания, но также имеется часть молодежи, желающая жить в исламском обществе, по законам шариата. Большая часть молодежи также желает жить в светском государственном устройстве Республики Дагестан, но также имеется немалая часть, которая выразила желание жить в исламском/религиозном государственном устройстве, с мотивировкой не столько религиозной, сколько бытовой, что это приведет к порядку. Данная позиция свидетельствует о неэффективности республиканских государственных властей, которая способствует усилению религиозно- 
го фактора у населения, в котором дагестанцы ищут честность, справедливость, порядок. Желание жить в светском обществе и государственном устройстве подтверждается позицией молодежи иметь связи со всеми государствами независимо от их религиозной, культурной, политической, экономической принадлежности, а религиозный фактор в данном вопросе имеет самое последнее значение. 7. В вопросах религиозно-политического радикализма дагестанская молодежь занимает отрицательную позицию, выраженную в негативном отношении к ИГИЛ, считая данную организацию террористической; отсутствием желания примкнуть в его ряды; отрицательным отношением к дагестанцам, находящимся в рядах террористических организаций; поддержкой российской государственной позиции и военных действий в Сирии против ИГИЛ и других террористических организаций и группировок.

Проведенное исследование показало, что религиозность среди дагестанской молодежи находится на достаточно высоком уровне, который особенно проявляется в некоторых вопpocax и вызывает определенную тревогу, но данное явление на сегодняшний день не носит тотального и критического характера. Молодежь остается приверженцем основ светскости, у которой экономический и политический фактор стоит выше религиозного, который играет больше духовно-нравственную, воспитательную роль. При этом молодежь достаточно трезво оценивает и поддерживает внешнеполитический курс федеральной власти Российской Федерации, в частности одобряет военно-политические действия в Сирийской Арабской Республике.

\section{ПРИМЕЧАНИЕ}

${ }^{1}$ Статья подготовлена в рамках проекта РГНФ № 17-03-50026 «Установки религиозно-политического радикализма в массовом сознании дагестанской молодежи».

\section{СПИСОК ЛИТЕРАТУРЫ}

1. Арчаков, М. К. Национальная безопасность России: проблемы противодействия политическому экстремизму / М. К. Арчаков // Чтения памяти
Евгения Петровича Сычевского. - 2014. - № 14. C. 4-13.

2. Бережной, С. Е. Исламский фундаментализм на юге России / С. Е. Бережной. - Ростов н/Д : Изд-во СКНЦВШ, 2004. - С. 87-88.

3. Боташева, А. К. Терроризм в современном политическом пространстве: истоки становления нелегитимного насилия и формирование международной антитеррористической системы / А. К. Боташева. - Ставрополь : Ставролит, 2013. - С. 23-31.

4. Видясова, М. Ф. Радикальные исламистские движения в Тунисе / М. Ф. Видясова // Исламские радикальные движения на политической карте современного мира: Страны Северной и Северо-Восточной Африки. - М. : ЛЕНАНД, 2015. - С. 258-281.

5. Винокуров, Ю. Н. Далеко ли революциям в Северной Африке до Африки южнее Сахары? / Ю. Н. Винокуров // Протестные движения в арабских странах: Предпосылки, особенности, перспективы: материалы конф. «круглого стола». - М. : ЛЕНАНД, 2015. - С. 90-96.

6. Гаджиев, К. С. Фундаментализм в поле пересечения западных и исламских ценностей / К. С. Гаджиев // Власть. - 2015. - № 3. - С. 5-13.

7. Горбатова, В. В. Исламский экстремизм и терроризм как категории политического анализа / В. В. Горбатова // Вестник Московского университета. Серия 12, Политические науки. - 2012. № 4. - С. 113-116.

8. Дегтярев, А. К. Исламизм: социологический дискурс / А. К. Дегтярев, В. В. Черноус // Россия и мусульманский мир. - 2011. - № 3. - С. 166-176.

9. Долгов, Б. В. Два лица умеренного исламизма / Б. В. Долгов // Азия и Африка сегодня. 2014. - № 7 (684). - С. 115-121.

10. Исаев, Л. В. Исламисты и политический процесс в Египте после «арабской весны» / Л. В. Исаев // Арабский кризис и его международные последствия. -М. : ЛЕНАНД, 2014.- С. 109-122.

11. Истомин, И. А. Политическая пропаганда радикальных исламистских организаций в США / И. А. Истомин // Вестник МГИМО университета. - 2012. - № 6 (27). - С. 94-103.

12. Кадырова, К. А. Основные тенденции практического применения концепции джихада в начале XXI в. / К. А. Кадырова // Вестник российского университета дружбы народов. Серия: Международные отношения. - 2014. - № 3. - С. 140-148.

13. Карпачева, О. В. Египет- родина современного исламского активизма на Ближнем Востоке / О. В. Карпачева // Исламские радикальные движения на политической карте современного мира: Страны Северной и Северо-Восточной Африки. М. : ЛЕНАНД, 2015. - С. 180-226.

14. Кислицын С. А. Международные террористические угрозы и безопасность России на пост- 
советском пространстве / С. А. Кислицын, О. В. Репинская // Известия высших учебных заведений. Северо-Кавказский регион. Серия: Общественные науки. - 2014. - № 6 (184). - С. 24-29.

15. Коротаев, А. В. Формирование «афразийской» зоны нестабильности / А. В. Коротаев, Л. М. Исаев // Арабский кризис и его международные последствия. - М. : ЛЕНАНД, 2014. - С. 206-227.

16. Косач, Г. Г. Ближний Восток: перманентная нестабильность / Г. Г. Косач // Мировая экономика и международные отношения. - 2015. - № 11. C. 120-127.

17. Косенко, Е. О. Глобализация как фактор появления новых форм терроризма / Е. О. Косенко, А. К. Боташева // Новое слово в науке: перспективы развития. - 2016. - № 2 (8). - С. 42-43.

18. Ланда, Р. Г. Политический ислам в странах Северной Африки / Р. Г. Ланда, А. Д. Саватеев // Исламские радикальные движения на политической карте современного мира: Страны Северной и Северо-Восточной Африки. - М. : ЛЕНАНД, 2015. C. $124-179$.

19. Малышева, Д. Б. Исламистское обличье африканских военных конфликтов / Д. Б. Малышева // Международная жизнь. - 2014. - № 11.-С. 113-126.

20. Медведев, Н. П. Влияние экстремизма и терроризма на конфликтогенность Северо-Кавказского региона / Н. П. Медведев // Вопросы политологии. - 2015. - № 2 (18). - С. 38-45.

21. Мирский, Г. И. Бен Ладен, «Аль-Каида» и судьба джихадизма / Г. И. Мирский // Мировая экономика и международные отношения. - 2011. № 12. - С. 31-48.

22. Наумкин, В. В. Исламский радикализм в зеркале новых концепций и подходов / В. В. Наумкин // Восток (Orient). - 2006. - № 1. - С. 5-25.

23. Носенко, В. И. Борьба с международным терроризмом и мусульманский мир / В. И. Носенко // Мировая экономика и международные отношения. -2007. - № 3. - С. 29-36.

24. Омаров, М. А. Религиозный фактор в политическом процессе / М. А. Омаров // Современная российская политика. - М. : Изд-во МГУ, 2013. C. $400-450$.

25. Петрухина, А. А. Теория и практика исламизма / А. А. Петрухина // Вестник российского университета дружбы народов. Серия: Международные отношения. - 2011. - № 2. - С. 102-109.

26. Примаков, E. М. «Islamic state» is a real danger / Е. М. Примаков // Азия и Африка сегодня. -2015 . - № 7. - С. 2-3.

27. Ражбадинов, М. 3. Ассоциация «братьямусульмане» и перспективы политических процессов в современном Египте / М. 3. Ражбадинов // Вестник МГИМО университета. - 2013. № 2 (29). - С. 42-46.
28. Саватеев, А. Д. Политический ислам в концепциях российских исследователей / А. Д. Саватеев // Ислам в современном мире. - 2015. - Т. 11, № 2. - С. 109-118.

29. Степанова, Е. А. Долгосрочный прогноз тенденций в области терроризма / Е. А. Степанова // Пути к миру и безопасности. - 2016. - № 1 (50). C. $39-52$.

30. Федорченко, А. В. Межконфессиональные противоречия в Саудовской Аравии: «шиитский вопрос» / А. В. Федорченко // Вестник МГИМО университета. - 2013. - № 2 (29). - С. 107-112.

31. Ханбабаев, К. М. Зарубежный опыт противодействия религиозно-политическому экстремизму и терроризму / К. М. Ханбабаев. - Махачкала : Лотос, 2011.- С. 138-144.

32. Хохлов, И. И. О некоторых подходах к объяснению феномена терроризма / И. И. Хохлов // Мировая экономика и международные отношения. - 2015. - № 5. - С. 19-28.

33. Чудинов, С. И. Терроризм смертников: проблемы научно-философского осмысления (на материале радикального ислама) / С. И. Чудинов. М. : Флинта : Наука, 2010. - С. 6-7.

34. Шахбанова, М. М. Религия как доминирующий фактор социальной жизни дагестанской молодежи / М. М. Шахбанова // Ориентиры самосознания молодежи в условиях глобального экстремизма и терроризма : материалы Всерос. науч.-практ. конф. - Махачкала : Изд-во Дагестан. гос. пед. ун-та, 2016. - C. 211-217.

35. Шахбанова, М. М. Этническая, религиозная и государственно-гражданская идентичности дагестанских народов в условиях трансформации российского общества / М. М. Шахбанова - Махачкала : Алеф, 2016. - С. 110-117.

36. Яшлавский, А. Э. Идеология салафитского джихадизма как тоталитарный проект / А. Э. Яшлавский // Мировая экономика и международные отношения. - 2013. - № 4. - С. 71-78.

37. Ali, T. Why we are so obsessed by Islam? Islam \& Europe: challenges and opportunities / T. Ali // Lectures Forum A. \& A. Leysen 2006-2007. - Leuven University Press, 2008. - P. 224-227.

38. Fuller, G. The future of political Islam /G. Fuller. -N. Y. : Palgrave Macmil-lan, 2003. - P.97-101.

39. Grigorian, V. Islam a Mosaic, not a monolith./ V. Grigorian. - Washington, 2003. - P. 56-62.

40. Halliday, F. The politics of the umma: states and community in Islamic movements / F. Halliday// Mediterranean Politics. - 2002. - Vol. 7, № 3. - P. 24-25.

41. Jansen, J. J. G. The Dual Nature of Islamic Fundamentalism/ J. J. G. Jansen. - L., 1997. - P. 19-21. 42. Lebl, S. L. Radical Islam in Europe / S. L. Lebl // Orbis. - 2010. - Vol. 54, № 1. - P. 46-50. 
43. Lewis, B. The Crisis of Islam / B. Lewis. - L., 2003. - P. 103-105.

44. Olcott, M. B. Soviet Islam and World Revolution / M. B. Olcott // World Politics. - 1982. Vol. 34, № 4. - P. 487-504.

45. Ramadan, T. Radical reform: Islamic ethics and liberation / T. Ramadan. - Oxford : University Press, 2009. - P. 84-85.

46. Yosoff, K. Islamic Radicalism in Malaysia: an overview / K. Yosoff// Procedia Social and Behavioral Sciences. -2010. - № 5. - P. 2326-2331.

\section{REFERENCES}

1. Archakov M.K. Natsionalnaya bezopasnost Rossii: problemy protivodeystviya politicheskomu ekstremizmu [National Security of Russia: Problems of Counteraction to Political Extremism]. Chteniya pamyati Evgeniya Petrovicha Sychevskogo [Reading in Memory of Evgeny Petrovich Sychevsky], 2014, no. 14, pp. 4-13.

2. Berezhnoy S.E. Islamskiy fundamentalizm na yuge Rossii [Islamic Fundamentalism in the South of Russia]. Rostov-on-Don, SKNTS VS Publ., 2004, pp. 87-88.

3. Botasheva A.K. Terrorizm v sovremennom politicheskom prostranstve: istoki stanovleniya nelegitimnogo nasiliya $i$ formirovanie mezhdunarodnoy antiterroristicheskoy sistemy [Terrorism in the Contemporary Political Space: Origins of the Formation of Illegitimate Violence and the Formation of an International Antiterrorist System]. Stavropol, Stavrolit Publ., 2013, pp. 23-31.

4. Vidyasova M.F. Radikal'nye islamistskie dvizheniya $\mathrm{v}$ Tunise [Radical Islamist Movements in Tunisia]. Islamskie radikalnye dvizheniya na politicheskoy karte sovremennogo mira: Strany Severnoy i Severo-Vostochnoy Afriki [Islamic Radical Movements on the Political Map of the Modern World: Countries of North and North-East Africa]. Moscow, LENAND Publ., 2015, pp. 258-281.

5. Vinokurov Yu.N. Daleko li revolyutsiyam v Severnoy Afrike do Afriki yuzhnee Sakhary? [Are Revolutions in North Africa far beyond sub-Saharan Africa?]. Protestnye dvizheniya $v$ arabskikh stranakh: Predposylki, osobennosti, perspektivy: materialy konf. «kruglogo stola» [Protest Movements in Arabic Countries: Background, Features, Prospects. Proceedings of the Round Table Conference]. Moscow, LENAND Publ., 2015, pp. 90-96.

6. Gadzhiev K.S. Fundamentalizm v pole peresecheniya zapadnykh i islamskikh tsennostey [Fundamentalism in the Field of Intersection of Western and Islamic Values]. Vlast, 2015, no. 3, pp. 5-13.
7. Gorbatova V.V. Islamskiy ekstremizm i terrorizm kak kategorii politicheskogo analiza [Islamic Extremism and Terrorism as a Category of Political Analysis]. Vestnik Moskovskogo universiteta. Seriya 12, Politicheskie nauki [Bulletin of Moscow University. Series 12, Political Science], 2012, no. 4, pp. 113-116.

8. Degtyarev A.K., Chernous V.V. Islamizm: sotsiologicheskiy diskurs [Islamism: Sociological Discourse]. Rossiia i musulmanskiy mir [Russia and the Muslim World], 2011, no. 3, pp. 166-176.

9. Dolgov B.V. Dva litsa umerennogo islamizma [Two Facets of Moderate Islamism]. Aziya i Afrika segodnya [Asia and Africa Today], 2014, no. 7 (684), pp. 115-121.

10. Isaev L.V. Islamisty i politicheskiy protsess $\mathrm{v}$ Egipte posle «arabskoy vesny» [Islamists and the Political Process in Egypt after the "Arab Spring"]. Arabskiy krizis i ego mezhdunarodnye posledstviya [The Arab Crisis and Its International Consequences]. Moscow, LENAND Publ., 2014, pp. 109-122.

11. Istomin I.A. Politicheskaya propaganda radikalnykh islamistskikh organizatsiy v SShA [Political Propaganda of Radical Islamist Organizations in the USA]. Vestnik MGIMO universiteta, 2012, no. 6 (27), pp. 94-103.

12. Kadyrova K.A. Osnovnye tendentsii prakticheskogo primeneniya kontseptsii dzhikhada $\mathrm{v}$ nachale XXI v. [The Main Trends in the Practical Use of the Conception of Jihad at the Beginning of the $21^{\text {st }}$ Century]. Vestnik rossiyskogo universiteta druzhby narodov. Seriya: Mezhdunarodnye otnosheniya, 2014, no. 3, pp. 140-148.

13. Karpacheva O.V. Egipet - rodina sovremennogo islamskogo aktivizma na Blizhnem Vostoke [Egypt is the Birthplace of Modern Islamic Activism in the Middle East]. Islamskie radikalnye dvizheniya na politicheskoy karte sovremennogo mira: Strany Severnoy i Severo-Vostochnoy Afriki [Islamic Radical Movements on the Political Map of the Modern World: Countries of North and North-East Africa]. Moscow, LENAND Publ., 2015, pp. 180-226.

14. Kislitsyn S.A., Repinskaia O.V. Mezhdunarodnye terroristicheskie ugrozy i bezopasnost Rossii na postsovetskom prostranstve [International Terrorist Threats and Russia's Security in the post-Soviet Space]. Izvestiya vysshikh uchebnykh zavedeniy. SeveroKavkazskiy region. Seriya: Obshchestvennye nauki, 2014, no. 6(184), pp. 24-29.

15. Korotaev A.V., Isaev L.M. Formirovanie «afraziyskoy» zony nestabilnosti [Formation of the "Afrasian" Zone of Instability]. Arabskiy krizis i ego mezhdunarodnye posledstviya [The Arab Crisis and Its International Consequences]. Moscow, LENAND Publ., 2014, pp. 206-227.

16. Kosach G.G. Blizhniy Vostok: permanentnaya nestabilnost [Middle East: Permanent Instability]. 
Mirovaya ekonomika $i$ mezhdunarodnye otnosheniya, 2015, no. 11, pp. 120-127.

17. Kosenko E.O., Botasheva A.K. Globalizatsiya kak faktor poyavleniya novykh form terrorizma [Globalization as a Factor in the Emergence of New Forms of Terrorism]. Novoe slovo v nauke: perspektivy razvitiya [A New Word in Science: Development Prospects], 2016, no. 2 (8), pp. 42-43.

18. Landa R.G., Savateev A.D. Politicheskiy islam v stranakh Severnoy Afriki [Political Islam in North Africa]. Islamskie radikalnye dvizheniya na politicheskoy karte sovremennogo mira: Strany Severnoy i Severo-Vostochnoy Afriki [Islamic Radical Movements on the Political Map of the Modern World: Countries of North and North-East Africa]. Moscow, LENAND Publ., 2015, pp. 124-179.

19. Malysheva D.B. Islamistskoe oblichye afrikanskikh voennykh konfliktov [The Islamist Appearance of African Military Conflicts]. Mezhdunarodnaia zhizn, 2014, no. 11, pp. 113-126.

20. Medvedev N.P. Vliyanie ekstremizma i terrorizma na konfliktogennost Severo-Kavkazskogo regiona [The Influence of Extremism and Terrorism on the Conflict of the North Caucasus Region]. Voprosy politologii [Issues of Political Science], 2015, no. 2 (18), pp. 38-45.

21. Mirskiy G.I. Ben Laden, «Al-Kaida» i sudba dzhikhadizma [Bin Laden, "Al-Qaeda" and the Fate of Jihadism]. Mirovaya ekonomika i mezhdunarodnye otnosheniya [World Economy and International Relations], 2011, no. 12, pp. 31-48.

22. Naumkin V.V. Islamskiy radikalizm v zerkale novykh kontseptsiy i podkhodov [Islamic Radicalism in the Mirror of New Concepts and Approaches]. Vostok (Orient), 2006, no. 1, pp. 5-25.

23. Nosenko V.I. Borba s mezhdunarodnym terrorizmom i musulmanskiymir [Fight against International Terrorism and the Muslim World]. Mirovaya ekonomika $i$ mezhdunarodnye otnosheniya [World Economy and International Relations], 2007, no. 3, pp. 29-36.

24. Omarov M.A. Religioznyy faktor v politicheskom protsesse [Religious Factor in the Political Process]. Sovremennaya rossiyskaya politika [Modern Russian Politics]. Moscow, Moscow State University Publ., 2013, pp. 400-450.

25. Petrukhina A.A. Teoriya i praktika islamizma [Theory and Practice of Islamism]. Vestnik rossiyskogo universiteta druzhby narodov. Seriya: Mezhdunarodnye otnosheniya [Bulletin of the Russian University of Peoples' Friendship. Series: International Relations], 2011, no. 2, pp. 102-109.

26. Primakov E.M. «Islamic state» is a real danger. Aziya i Afrika segodnya [Asia and Africa Today], 2015, no. 7, pp. 2-3.

27. Razhbadinov M.Z. Assotsiatsiya «bratyamusulmane» i perspektivy politicheskikh protsessov v sovremennom Egipte [Association "Muslim Brothers" and the Perspectives of Political Processes in Modern Egypt]. Vestnik MGIMO universiteta, 2013, no. 2 (29), pp. 42-46.

28. Savateev A.D. Politicheskiy islam v kontseptsiyakh rossiyskikh issledovateley [Political Islam in the Conceptions of Russian Researchers]. Islam v sovremennom mire [Islam in the Modern World], 2015, vol. 11, no. 2, pp. 109-118.

29. Stepanova E.A. Dolgosrochnyy prognoz tendentsiy v oblasti terrorizma [Long-Term Forecast of Trends in the Field of Terrorism]. Puti $k$ miru $i$ bezopasnosti [Ways to Peace and Security], 2016, no. 1 (50), pp. 39-52.

30. Fedorchenko A.V. Mezhkonfessionalnye protivorechiya v Saudovskoy Aravii: «shiitskiy vopros» [Interconfessional Contradictions in Saudi Arabia: Shiite Issue]. Vestnik MGIMO universiteta, 2013, no. 2 (29), pp. 107-112.

31. Khanbabaev K.M. Zarubezhnyy opyt protivodeystviya religiozno-politicheskomu ekstremizmu i terrorizmu [Foreign Experience of Countering Religious and Political Extremism and Terrorism]. Makhachkala, Lotus Publ., 2011, pp. 138-144.

32. Khokhlov I.I. O nekotorykh podkhodakh $\mathrm{k}$ obyasneniyu fenomena terrorizma [About Some Approaches to Explaining the Phenomenon of Terrorism]. Mirovaya ekonomika i mezhdunarodnye otnosheniya [World Economy and International Relations], 2015, no. 5, pp. 19-28.

33. Chudinov S.I. Terrorizm smertnikov: problemy nauchno-filosofskogo osmysleniya (na materiale radikalnogo islama) [Suicide Terrorism: Problems of Scientific and Philosophical Interpretation (on the Basis of Radical Islam)]. Moscow, Flint; Nauka Publ., 2010, pp. 6-7.

34. Shakhbanova M.M. Religiya kak dominiruyushchiy faktor sotsialnoy zhizni dagestanskoy molodezhi [Religion as the dominant factor in the social life of youth in Dagestan]. Orientiry samosoznaniya molodezhi $v$ usloviyakh globalnogo ekstremizma i terrorizma: materialy Vseros. nauch.prakt. konf. Makhachkala, Izd-vo Dagestan. gos. ped. un-ta, 2016, pp. 211-217.

35. Shakhbanova M.M. Etnicheskaya, religioznaya $i$ gosudarstvenno-grazhdanskaya identichnosti dagestanskikh narodov $v$ usloviyakh transformatsii rossiyskogo obshchestva [Ethnic, Religious and State-Civil Identity of the Dagestan Peoples in the Conditions of Russian Society Transformation]. Makhachkala, AlefPubl., 2016, pp. 110-117.

36. Yashlavskiy A.E. Ideologiya salafitskogo dzhikhadizma kak totalitarnyy proekt [Ideology of Salafi Jihadism as a Totalitarian Project]. Mirovaya ekonomika i mezhdunarodnye otnosheniya, 2013, no. 4, pp. 71-78. 
P.M. Мамараев. Религиозно-политические установки в массовом сознании дагестанской молодежи

37. Ali T. Why We Are so Obsessed by Islam? Islam \& Europe: Challenges and Opportunities. Lectures Forum A. \& A. Leysen 2006-2007. Leuven University Press, 2008, pp. 224-227.

38. Fuller G. The Future of Political Islam. New York, Palgrave Macmillan, 2003, pp. 97-101.

39. Grigorian V. Islam a Mosaic, not a Monolith. Washington, 2003, pp. 56-62.

40. Halliday F. The Politics of the Umma: States and Community in Islamic Movements. Mediterranean Politics, 2002, vol. 7, no. 3, pp. 24-25.

41. Jansen J.J.G. The Dual Nature of Islamic Fundamentalism. London, 1997, pp. 19-21.
42. Lebl S.L. Radical Islam in Europe. Orbis, 2010, vol. 54, no. 1, pp. 46-50.

43. Lewis B. The Crisis of Islam. London, 2003, pp. 103-105.

44. Olcott M.B. Soviet Islam and World Revolution. World Politics, 1982, vol. 34, no. 4, pp. 487-504.

45. Ramadan T. Radical reform: Islamic ethics and liberation. Oxford, University Press, 2009, pp. 84-85.

46. Yosoff K. Islamic Radicalism in Malaysia: an overview. Procedia Social and Behavioral Sciences, 2010, no. 5, pp. 2326-2331.

\section{Information about the Author}

Ruslan M. Mamaraev, Researcher, Department of Sociology, Institute for History, Archaeology and Ethnography of the Dagestan Scientific Centre, Russian Academy of Sciences, M. Yaragskogo St., 75, 367030 Makhachkala, Russian Federation, ruslan070@inbox.ru, http://orcid.org/0000-0002-6134-243X

\section{Информация об авторе}

Руслан Магомедсаламович Мамараев, научный сотрудник Отдела социологии, Институт истории, археологии и этнографии ДНЦ РАН, ул. М. Ярагского, 75, 367030 г. Махачкала, Российская Федерация, ruslan070@inbox.ru, http://orcid.org/0000-0002-6134-243X 